\title{
Effect of photoperiod on the host attachment and development in the tick, Haemaphysalis longicornis
}

\author{
Kazuyoshi Fu jıмото* \\ Department of Medical Zoology, Saitama Medical School, \\ Moroyama-machi, Saitama 350-04, Japan
}

(Received: 13 March 1995; Accepted: 8 August 1995)

Key words: Haemaphysalis longicornis, development, host attachment, photoperiod, diapause.

\begin{abstract}
The effects of photoperiod on host attachment activity and development in the tick, Haemaphysalis longicornis, were observed at $25^{\circ} \mathrm{C}$ under two photoperiodic conditions (10L-14D and 16L-8D). The development of engorged larvae and engorged nymphs was hardly affected by photoperiod during the stages from egg to engorged larva or engorged nymph. However, the host attachment activities of unfed nymphs and unfed adults were significantly suppressed by exposure to a short-day photoperiod (10L-14D) during the stages from egg to unfed nymph or unfed adult. These results suggest that diapause occurs in unfed nymphs and unfed adults which were exposed to short-day photoperiod, but not in engorged larvae and engorged nymphs. In Saitama Prefecture, the disappearance of $H$. longicornis nymphs in autumn may be related to the diapause of the unfed nymphs. However, the low activity of the adults in autumn can not be fully explained by the diapause, because the adults develop in the long-days of spring to summer.
\end{abstract}

\section{INTRODUCTION}

Haemaphysalis longicornis Neumann is well known as the most harmful tick in pastures (Kitaoka et al., 1975; Ootake et al., 1985) and as a vector for theileriosis caused by Theileria sergenti Yakimoff and Dekhtereff (Ishii and Ishihara, 1951). Therefore, there have been many ecological studies on this tick in Japan (Namba, 1958; Yoshida, 1975, 1980; Chikaki, 1976; Shiraishi et al., 1982, 1989; Ito et al., 1983; Kakuda et al., 1990). However, the life cycle of this tick

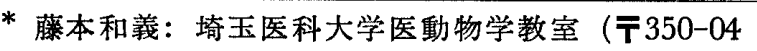
埼玉県入間郡毛呂山町毛呂本郷 38)
}

is not fully analyzed in these reports. In general, the life cycles of ticks are controlled by various meteorological factors. Especially, diapause controlled by photoperiod has an important role in the seasonal regulation of the life cycles of many tick species (Belozerov, 1982). The present study examines the effect of photoperiod on host attachment activity and development in the tick, $H$. longicornis, and clarifies whether diapause occurs in this tick or not.

\section{Materials and Methods}

Tick rearing. H. longicornis used in this study were derived from adults collected by the flagging method at a hilly area in Saitama 
Prefecture. The adults collected were fed on the ears of domestic rabbits in the laboratory, maintained at $25 \pm 3^{\circ} \mathrm{C}$, and with a 16L-8D photoperiod ( $16 \mathrm{hr}$ light $/ 8 \mathrm{hr}$ dark). Ear bags were used for feeding adult ticks on rabbits. The engorged females dropped off from the host rabbits were placed in tick containers (Petri dishes $4.5 \mathrm{~cm}$ in diameter) with wet filter papers at the bottom, and kept in an incubator $\left(25^{\circ} \mathrm{C}, 16 \mathrm{~L}-8 \mathrm{D}\right.$ photoperiod). The eggs deposited by the females were placed daily in tick containers $3.0 \mathrm{~cm}$ in diameter) and incubated at $25^{\circ} \mathrm{C}$ under two photoperiodic conditions $(10 \mathrm{~L}-14 \mathrm{D}$ and $16 \mathrm{~L}-8 \mathrm{D})$. Two groups (10L-14D and 16L$8 \mathrm{D}$ groups) of the larvae and nymphs used in this study were derived from these eggs reared under each photoperiodic condition. Two groups of the larvae and nymphs were fed on the ears of domestic rabbits under $25 \pm 3^{\circ} \mathrm{C}$ and each photoperiodic condition. Two groups of the engorged larvae and engorged nymphs detached were placed in tick containers, and reared at $25^{\circ} \mathrm{C}$ under each photoperiodic condition.

Effect of photoperiod on the host attachment of unfed ticks. The "ear bag method" was used in this experiment. Each of the two groups of unfed nymphs and unfed adults ( 1 to 4 months old after molting) was taken at an infestation density from 60 to 100 per ear bag for nymphs, and from 15 to 20 per ear bag for adults. The ear bags which covered the ears of a domestic rabbit were fixed with adhesive plaster on the ear base. The tick-infested rabbits were kept in the laboratory, maintained at $25 \pm 3^{\circ} \mathrm{C}$, and with a $16 \mathrm{~L}-8 \mathrm{D}$ photoperiod. The attached ear bags were kept for $8 \mathrm{hr}$ after infestation and subsequently removed from the ears of domestic rabbits. The number of attached ticks was counted for each group to calculate the rate of host attachment.

Effect of photoperiod on the development of engorged ticks. Each of two groups of detached engorged larvae and engorged nymphs from the host rabbits on the same day were placed together in batches of 10 to 15 individuals in tick containers for larvae, and one to 5 individuals for nymphs, and kept in incubators at $25^{\circ} \mathrm{C}$ under each photoperiodic condition. The developmental periods (days from drop-off to the following ecdysis) and the percentages of molting in engorged larvae and engorged nymphs were recorded at each photoperiodic condition.

\section{Results}

Effect of photoperiod on the host attachment of unfed ticks

As shown in Table 1, the mean rates of host attachment in nymphs exposed to 16L8D and 10L-14D photoperiods during the stages from egg to unfed nymph were 60.4 and $34.2 \%$, respectively. There was a significant difference in the rate of host attachment in nymphs between $16 \mathrm{~L}-8 \mathrm{D}$ and $10 \mathrm{~L}-$ 14D) $\left(x^{2}=56.21, p<0.001\right)$. On the other hand, the rate of host attachment of adults exposed to $16 \mathrm{~L}-8 \mathrm{D}$ during the stages from egg to unfed adult averaged $74.5 \%$, but that of adults exposed to $10 \mathrm{~L}-14 \mathrm{D}$ was $0 \%$ (Table 2 ). A significant difference was found between the rates of host attachment in adults exposed to $16 \mathrm{~L}-8 \mathrm{D}$ and in those exposed to 10L-14D $\left(\chi^{2}=83.71, p<0.001\right)$.

Table 1 Percentage of host attachment of $H$. longicornis nymphs exposed to two photoperiodic conditions from egg to unfed nymph.

\begin{tabular}{lccc}
\hline \hline $\begin{array}{c}\text { Photoperiodic } \\
\text { conditions } \\
\text { (hr) }\end{array}$ & $\begin{array}{c}\text { No. of } \\
\text { rabbits } \\
\text { used }\end{array}$ & $\begin{array}{c}\text { Total No. } \\
\text { of nymphs } \\
\text { used }\end{array}$ & $\begin{array}{c}\text { Mean \% } \\
\text { attachment }\end{array}$ \\
\hline 10L-14D & 4 & 386 & 34.2 \\
16L-8D & 4 & 432 & 60.4 \\
\hline
\end{tabular}

Table 2 Percentage of host attachment of $H$. longicornis adults exposed to two photoperiodic conditions from egg to unfed adult.

\begin{tabular}{cccc}
\hline $\begin{array}{c}\text { Photoperiodic } \\
\text { conditions } \\
\text { (hr) }\end{array}$ & $\begin{array}{c}\text { No. of } \\
\text { rabbits } \\
\text { used }\end{array}$ & $\begin{array}{c}\text { Total No. } \\
\text { of adults } \\
\text { used }\end{array}$ & $\begin{array}{c}\text { Mean \% } \\
\text { attachment }\end{array}$ \\
\hline 10L-14D & 2 & 78 & 0 \\
16L-8D & 2 & 55 & 74.5 \\
\hline
\end{tabular}


Table 3 Development of engorged $H$. longicornis larvae reared at $25^{\circ} \mathrm{C}$ under two photoperiodic conditions from egg to engorged larva.

\begin{tabular}{cccc}
\hline \hline $\begin{array}{c}\text { Photoperiodic conditions } \\
(\mathrm{hr})\end{array}$ & $\begin{array}{c}\text { No. of engorged } \\
\text { larvae examined }\end{array}$ & $\begin{array}{c}\text { Mean developmental period } \\
\text { in days* }\end{array}$ ( \pm S.D.) & $\begin{array}{c}\% \\
\text { molting }\end{array}$ \\
\hline 10L-14D & 110 & $12.2( \pm 0.9)$ & 100 \\
16L-8D & 123 & $12.8( \pm 1.6)$ & 96.7 \\
\hline
\end{tabular}

* Days from drop-off to the following ecdysis. S.D.: standard deviation.

Table 4 Development of engorged $H$. longicornis nymphs reared at $25^{\circ} \mathrm{C}$ under two photoperiodic conditions from egg to engorged nymph.

\begin{tabular}{cccc}
\hline $\begin{array}{c}\text { Photoperiodic conditions } \\
(\mathrm{hr})\end{array}$ & $\begin{array}{c}\text { No. of engorged } \\
\text { nymphs examined }\end{array}$ & $\begin{array}{c}\text { Mean developmental period } \\
\text { in days* }( \pm \text { S.D. })\end{array}$ & $\begin{array}{c}\% \\
\text { molting }\end{array}$ \\
\hline 10L-14D & 86 & $12.7( \pm 1.0)$ & 97.7 \\
16L-8D & 47 & $14.3( \pm 1.0)$ & 100 \\
\hline
\end{tabular}

* Days from drop-off to the following ecdysis. S.D.: standard deviation.

\section{Effect of photoperiod on the development of engorged ticks}

As shown in Table 3, the mean developmental periods of engorged larvae exposed to $16 \mathrm{~L}-8 \mathrm{D}$ and $10 \mathrm{~L}-14 \mathrm{D}$ photoperiods during the stages from egg to engorged larva were 12.8 and 12.2 days, respectively. The molting percentages of the engorged larvae exposed to $16 \mathrm{~L}-8 \mathrm{D}$ and $10 \mathrm{~L}-14 \mathrm{D}$ were 96.7 and $100 \%$, respectively. On the other hand, the mean developmental periods of engorged nymphs exposed to $16 \mathrm{~L}-8 \mathrm{D}$ and $10 \mathrm{~L}-14 \mathrm{D}$ photoperiods during the stages from egg to engorged nymph were 14.3 and 12.7 days, respectively (Table 4 ). The molting percentages of the engorged nymphs exposed to $16 \mathrm{~L}-$ $8 \mathrm{D}$ and $10 \mathrm{~L}-14 \mathrm{D}$ were 100 and $97.7 \%$, respectively.

\section{Discussion}

Diapause in ticks is classified into two types; i.e., behavioral (host-seeking) diapause and morphogenetic (developmental) diapause (Belozerov, 1982). Behavioral diapause is characterized by the suppression of host attachment activity (host-seeking activity) in unfed ticks, and morphogenetic diapause results from the delay in reproduction and development in engorged ticks. In this study, the development of engorged larvae was little affected by the photoperiodic conditions that they experienced during the stages from egg to engorged larva. Further, photoperiod had little effect on the development of engorged nymphs, although the developmental period was slightly prolonged only when they were exposed to a long-day photoperiod (16L-8D) during the stages from egg to engorged nymph. These results suggest that morphogenetic diapause does not occur in engorged larvae and engorged nymphs. On the other hand, the host attachment activities of unfed nymphs and unfed adults were significantly suppressed when they were exposed to a short-day photoperiod (10L-14D) during the stages from egg to unfed nymph or adult. This suggests that behavioral diapause occurs in unfed nymphs and unfed adults as a result of exposure to short-day photoperiod.

At a hilly area in Saitama Prefecture, $H$. longicornis nymphs were collected on vegetation from April through July with a peak in May, and the adults from May through September with a peak in July (Fujimoto, unpublished). The seasonal activities of the nymphs and adults on vegetation were characterized by the disappearance or low activity 
in autumn. The diapause in unfed $H$. longicornis nymphs induced by short-days photoperiod may be related to the disappearance of the nymphs in autumn in Saitama Prefecture, because most of the nymphs develop in the short-days of autumn. However, the low activity of $H$. longicornis adults in autumn can not be fully explained by the diapause, because the adults develop in the longdays of spring to summer.

\section{AGKNoWledgement}

The author wishes to thank Prof. E. Hori of the Saitama Medical School for his critical reading of the manuscript.

\section{REFERENGES}

Belozerov, V. N. (1982) Diapause and biological rhythms in ticks. In: Physiology of Ticks (ed., Obenchain, F. D. and R. Galun), pp. 469-500, Pergamon Press, Oxford.

Chikaki, H. (1976) Biological studies on Haemaphysalis longicornis. Spec. Rep. Insect Management Lab. Fac. Agric. Shimane Univ., (1) : 1-76 (in Japanese with English summary).

Ishii, S. and T. Ishihara (1951) Studies of ticks carrying minor piroplasma. J. Jpn. Vet. Med. Assoc., 4: 289-292 (in Japanese).

Ito, Y., N. Watanabe and T. Matsumura (1983) Overwintering of Haemaphysalis longicornis (Acari: Ixodidae) at a pasture, Nasu Plateau, Japan. Bull. Natl. Grassl. Res. Inst., 24: 110118 (in Japanese with English summary).

Kakuda, H., S. Shiraishi and T. A. Uchida (1990) Seasonal fluctuations of populations and effects of temperatures on development and growth in the tick, Haemaphysalis flava. J. Fac. Agric. Kyushu Univ., 35: 17-26.

Kitaoka, S., T. Morii and K. Fujisaki (1975) Consideration on the grazing cattle-tick relationship in Japan, with special reference to large wild mammals and the deer-tick ecosystem in the Tanzawa Mountains. Bull. Natl. Inst. Anim. Health, 70: 35-42 (in Japanese).

Namba, N. (1958) Ecological studies on Haemaphysalis bispinosa, a harmful tick in the pasture of northern Japan. Hokkaido Natl. Agric. Exp. Stn. Rep., 50: 1-99 (in Japanese with English summary).

Ootake, H., I. Ito and K. Hayashi (1985) Relationships between population density of the tick, $H$. longicornis, and environmental factors in the permanent pasture. I. Ixodid fauna and seasonal fluctuation of the tick, $H$. longicornis, in Kawatabi. J. Jpn. Grassl. Sci., 30: 452-457 (in Japanese with English summary).

Shiraishi, S., T. Mori, K. Funakoshi, S. Arai, N. Kawaji, M. Nishimura and T. A. Uchida (1982) Fundamental studies on the control of the cattle tick, Haemaphysalis longicornis, at Kuju Highland. I. Preliminary report on the ecology of the tick. Sci. Bull. Fac. Agric. Kyushu Univ., 36: 101-114 (in Japanese with English summary).

Shiraishi, S., K. Yoshino and T. A. Uchida (1989) Studies on seasonal fluctuations of populations and overwintering in the cattle tick, Haemaphysalis longicornis. J. Fac. Agric. Kyushu Univ., 34: 43-52.

Yoshida, T. (1975) Ecological studies for the control of the tick in the pasture. J. Fac. Liberal Arts. Shinshu Univ., 9: 27-111 (in Japanese with English summary).

Yoshida, T. (1980) Ecology of the tick, Haemaphysalis longicornis, in the pasture of Japan. Biol. Sci., 32: 1-10 (in Japanese).

\section{摘 要 \\ フタトゲチマダニの宿主への寄生と発育に 及ぼす日長の影響}

フタトゲチマダニの幼虫, 若虫, 成虫の宿主への 寄生と発育を $25^{\circ} \mathrm{C}$ 一定で, 日長条件 (10L-14D, 16L-8D) を変えて観察した。 飽血幼虫および飽血若 虫の発育は, 卵期から長日条件 $(16 \mathrm{~L}-8 \mathrm{D})$ で飼育し ても，短日条件 (10L-14D) で飼育しても，ほとんど 変わらなかった。 しかし，未吸血若虫および未吸血成 虫の宿主への寄生は卵期から短日条件で飼育した場 合，著しく阻害された。これらの結果は，フタトゲチ マダニの未吸血若虫と末吸血成虫は，短日条件で䏍っ た場合，休眠に入るが，飽血幼虫と飽血若虫は，日長 条件にかかわらず，休眠に入らないことを示唆する。

埼玉県において，秋に若虫が出現しないのは，秋の 短日条件下で発育した若虫が休眠に入るためかもし れない。しかし，秋における成虫の不活発な活動は， 成虫が春から夏の長日条件下で発育寸ることから，休 眠によって説明できない。 